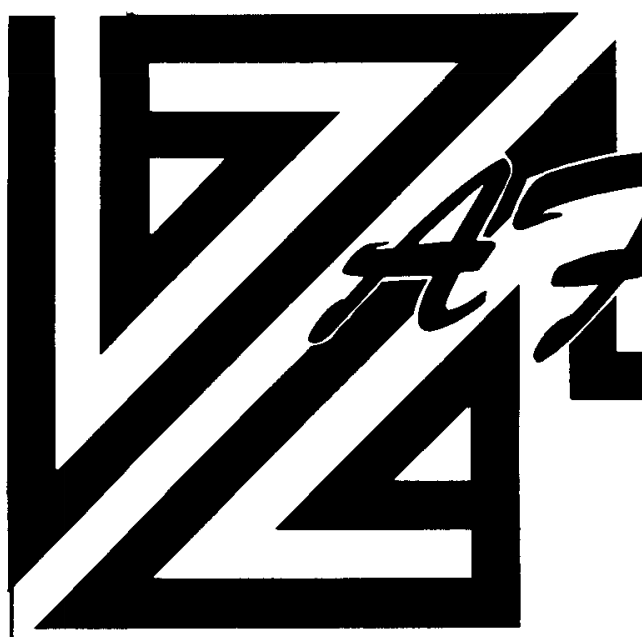

BLACK AND AFRICAN THEOLOGIES

Siblings or Distant Cousins? JOSIAHU. YOUNG

"Interdisciplinary . . ecumenical . . brilliant."

- GLORIA WADE-GAYLES Paper $\$ 13.95$

\section{AFRICAN CHRISTIAN THEOLOGY \\ Adaptation or Incarnation? \\ AYLWARD SHORTER}

"An important and well-stated contribution to the literature on African religion." - Choice Paper $\$ 12.95$

\section{JESUS AND THE WITCHDOCTOR}

An Approach to Healing and Wholeness AYLWARD SHORTER

Encounters with the tradition of the witchdoctor and the notion and practice of integral healing. Paper $\$ 12.95$

\section{A FIFTH GOSPEL}

The Experience of Black Christian Values JOSEPH G. HEALEY

"The most timely and most representative work that we can look to on the life of small Christian communities in

Africa."-REV. JOSEPH KALEM'LMANA, Tanzania

Paper $\$ 9.95$

\section{MY FAITH AS AN AFRICAN}

JEAN-MARC ELA

Jean-Marc Ela challenges us to reread the Gospels with African eyes. "Exciting and moving. ..'-MARIE GIBLIN Paper $\$ 9.95$

\section{R? CA POLITICS AND RELIGION}

TRAPPED IN APARTHEID

A Socio-Theological History of the

English Speaking Churches in South Arrica CHARLES VILLA-VICENCIO

Foreword by Bishop Trevor Huddleston

"A devastating indictment of the so-called anti-apartheid churches." - BISHOP DESMOND M. TUTU Paper \$11.95

\section{THE MISSIONARY AND THE DIVINER Contending Theologies of Christian and African Religions MICHAEL C. KIRWEN}

"An exciting book, a disturbing yet persuasive contribution to missiology."-GREGORY BAUM Cloth $\$ 19.95$, Paper $\$ 9.95$

\section{FAREWELL TO INNOCENCE}

A Socio-Ethical Study on Black Theology and Black Power

ALLAN A. BOESAK

Boesak relates black South African experience to liberation movements. Paper $\$ 9.95$

\section{THE UNQUESTIONABLE RIGHT TO BE FREE} Essays in Black Theology from South Africa ITUMELENG J. MOSALA and BUTI TLHAGALE, editors

"A significant contribution to identifying and defining the issues."-Best Sellers Paper $\$ 11.95$

\section{HEARING AND KNOWING}

Theological Reflections on Christianity in Africa MERCY AMBA ODUYOYE

"Oduyoye's writings are like a breath of fresh air. -KATIE G. CANNON Paper $\$ 10.95$

At bookstores or from

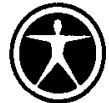

\title{
Orbis Baaks
}

Maryknoll, NY 10545 • 1-800-258-5838 - In NYS call collect 914-941-7687

Orbis Books is represented to the trade by Abingdon Press. 


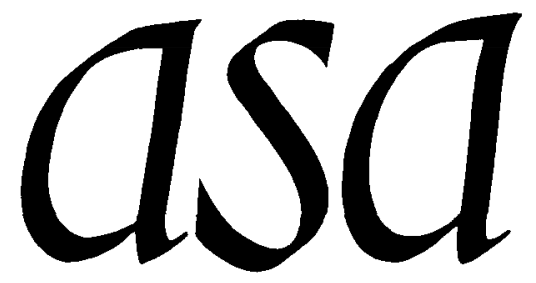

\section{AFRICAN STUDIES}

ASSOCIATION

The AFRICAN STUDIES ASSOCIATION was organized in 1957 as a non-profit corporation to bring together persons with a scholarly and professional interest in Africa, to provide useful services to the Africanist community, and to publish and distribute scholarly materials on Africa. Membership is open to individuals and institutions.

An ANNUAL MEETING each autumn provides an occasion for panels, plenary sessions and discussion groups, exhibits and films. Participants from North America, Africa and Europe gather for this Meeting which is held in different regions of the US in cooperation with major universities and museums, and under the program direction of a distinguished Africanist. The annual business meeting of the members of the ASA takes place at that time. ASA members register for the Annual Meeting and purchase copies of papers presented at the Meeting at discounted rates.

\section{MEMBERS RECEIVE THREE REGULAR PUBLICATIONS:}

AFRICAN STUDIES REVIEW publishes review articles, essays of scholarly and bibliographical substance, and reviews of recent books in African studies. Editor: Carol B. Thompson.

ISSUE: A JOURNAL OF OPINION, an occasional publication, presents provocative and timely comment on critical developments in Africa and African studies. Editor: Harvey Glickman.

ASA NEWS, a quarterly newsletter, reports current and future activities of the Association, bibliographical and news notes, employment notices, significant correspondence and announcements of concern to the world community of Africanists. Editor: Edna G. Bay.

\section{MEMBERSHIP DUES:}

\section{Institutions:}

$\$ 75$ domestic and surface overseas;

$\$ 55$ surface overseas for institutions on the

African continent;

$\$ 90$ overseas airmail to Europe or Africa

Individuals:

$\$ 45$ members earning over $\$ 30,000$;

$\$ 35$ members earning less than $\$ 30,000$;

$\$ 15$ student, retired and unemployed (5-year limit);

$\$ 80$ airmail (for addresses outside North America)

\section{ADDRESS:}

African Studies Association

Credit Union Building

Emory University

Atlanta, GA 30322 

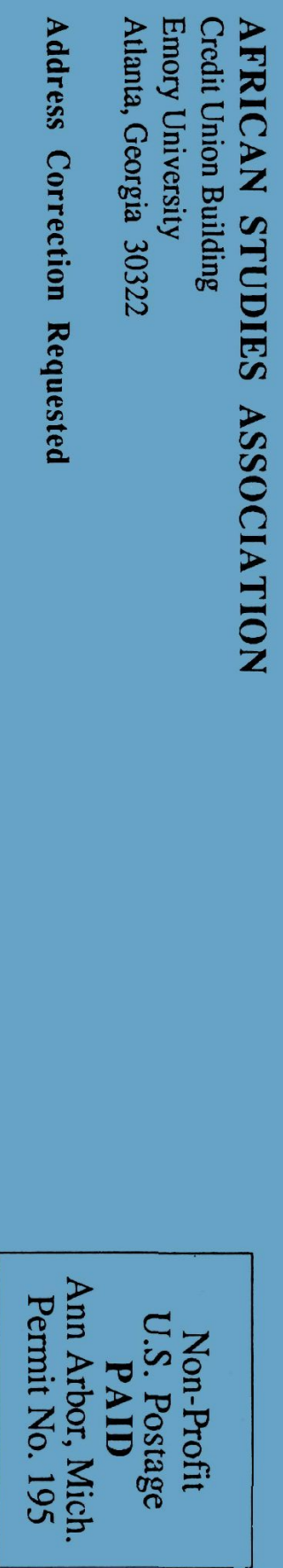